\title{
Leadership Styles and Attributes of Prominent Women Business Leaders: A Case Study
}

\author{
Zarifah Abdullah*, Natrah Saad, Noor Afza Amran \& Marhaiza Ibrahim \\ Tunku Puteri Intan Safinaz School of Accountancy, Universiti Utara Malaysia, \\ Sintok, Kedah, Malaysia
}

Received: 27/9/2019 Revised: 26/4/2020 Accepted: 20/5/2020 Published: 30/6/2020

\begin{abstract}
Malaysia is encouraging the involvement and participation of women in developing its economy and in transforming it to become a developed nation by the year 2020. However, studies that look into the attributes of successful women business leaders are scarce. Hence, it is the focus of this paper to reveal the attributes of prominent women business leaders and their respective leadership styles. Three (3) prominent women business leaders from various industries participated in this study and data were gathered through qualitative semi-structured interviews. It was found that the attributes possessed by these participants are similar to their male counterparts. The only differences between men and women business leaders are in terms of $(i)$ the amount of focus time spent between domestic chores and work, and (ii) the motherly/ sisterly approach portrayed by the participants, which is unique to women business leaders. The participants demonstrated three styles of leadership, namely paternalistic, transformational, and participative.
\end{abstract}

Keywords: Prominent women business leaders, attributes, leadership styles, qualitative case study

\subsection{Introduction}

Malaysia, being a responsible government, is placing its utmost priority toward increasing the number of women into decision-making positions (Merican \& Ghani, 2016). In order to achieve the goal of becoming a developed nation by 2020 , women must be enabled and empowered to fulfil their potential as the driving force that will propel the nation to greater heights. This is crucially important when looking at the statistics that women form about $49 \%$ of the total population in Malaysia (Malaysia Demographics Profile 2019).

* Corresponding Author Email: zarifah@uum.edu.my 
However, this task is never an easy one as a lot of effort needs to be put in by various sectors to ensure its success. For the government, it is not only the issue of equal opportunity and rights, but also it is a fact that makes economic sense since "investing in women is smart economics" (Revenga \& Shetty, 2012; Perianes, 2018). Notwithstanding the importance of this national agenda, limited studies have, however, been done to understand the attributes of successful women in business organisations. It is important to note that those studies undertaken, such as Idris (2008), Alam, Jani, and Omar (2011), and Karim and Azmi (2008), were mainly focusing on women in small and medium-sized enterprises (SMEs). Without denying that learning the success factors of those entrepreneurs are important, the researchers also believe that examining the attributes of prominent women business leaders, namely the CEOs and founders of established business organisations, regardless of whether the business organisations are SMEs or large corporations, are even more crucial considering their ability to compete in a more competitive environment. As the role models in private sectors, the stories of their success may spark interest of young women entrepreneurs and fresh graduates to venture into the business sector.

The bigger objective of this research was to be able to contribute to a faster rate of women participation into the top management and decision making level as intended by the government. Hence, by studying the attributes and leadership styles of some prominent women business leaders, it is hoped that this research would be able to capture some of the important attributes and leadership styles. By knowing these, it is hoped that it would provide some insights to the related ministries, such as the Ministry of Education and the Ministry of Women, Family, and Community Development, in enhancing their educational or developmental programmes.

Thus, it is vital to reveal what the attributes of these prominent women business leaders are, that make them who they are today. How did they manage their businesses and lead their staff and employees that make them successful and sustain in their respective business niche? It is hoped by understanding the leading attributes and leadership styles of these prominent women business leaders, one is able to develop youngsters and children at schools with those attributes. Hence, it is the interest of this paper to unveil the attributes of prominent Malaysian women business leaders and their respective leadership styles, irrespective of whether their business organisations are SMEs or large corporations.

\subsection{Literature Review}

\subsection{Role of Women Leaders in Malaysia}

The global issue of women's participation in management is also felt in Malaysia as the educational level of women has improved tremendously (Ministry of Women, Family, 
and Community Development, Malaysia (2019); Aziz, 2016). In fact, in recent years, the majority of students in tertiary education are females. In 2018, there were $61.92 \%$ females at public higher education institutions in Malaysia (Department of Statistics Malaysia, 2019). As indicated by the statistics from the Department of Statistics Malaysia (2019), more women are entering into the workforce. The labour force participation rate in 2019 has shown a $55.2 \%$ (54.3\% in 2017) of women participation in the Malaysian workforce as compared to $80.4 \%$ (80.2\% in 2017) of men participation (Department of Statistics Malaysia, 2019). The level of women participation in legislative, senior official, and managerial positions is only $24.7 \%$ and in professional and technical positions is about $44.3 \%$ in 2019 (Department of Statistics Malaysia, 2019). Hirschmann's (2020) survey of the business sector in Malaysia in 2015 found that less than $14 \%$ of all board members were female. Ku Ismail, Amran, Aripin, et al. (2017) surveyed women representation on boards of Malaysian companies and found that not much improvement has been made as far as that aspect is concerned. Thus, the pool of potential and qualified women who could serve at the top management level is large. However, women's representation in Malaysian companies has not been reflective of the workforce statistics. With regard to the impact of women leaders on company performance, Wartzman (2013) mentioned a report in the Times that companies with at least one female director were $20 \%$ less likely to file bankruptcy and that companies with higher representations of females on their boards had better financial performance. Such finding was supported by previous studies that provide evidence for better firm performance with more women participation on board (Abdullah et al., 2016; Ku Ismail et al., 2017).

In 2018, 54.7\% of women were already in the workforce in Malaysia and it was targeted that it will reach 59\% by 2020 (The New Straits Times, Sep 24, 2018). In response to this, the Malaysian Cabinet has approved a policy that women must comprise at least $30 \%$ of female population in decision-making positions in the corporate sector by 2030 (The New Straits Times, Sep 24, 2018). This decision shows that the Malaysian Government is not only supportive of women's roles and success, but also encourages them to move further ahead in their careers.

According to the Institute of Corporate Directors Malaysia, women representation in boardrooms of public-listed companies in Bursa Malaysia is moving at a slower pace, i.e., 16.6\% of total board seats in 2019 as compared to $15.6 \%$ in 2018 (The Star, 2019). This is supported by the 2018 Hays Asia Salary Guide which reported that women held $35 \%$ of management roles in Malaysia in 2017, and in 2018, the figure increased to $38 \%$, which indicated that the number of women in management is increasing, albeit slowly (Hays, 2018). With the current slow stage of increase in women involvement at the management level, it would be good to learn the various leadership styles and attributes possessed by the prominent women business leaders in Malaysia in order to enhance women's capability to be at such positions. 
The authors refer to prominent women business leaders as business women who are very noticeable, important, or famous in their respective business niche, and since this study was conducted in Malaysia, the focus would be on prominent Malaysian women business leaders. Someone would be regarded as prominent when the minute the name is mentioned people will know who that person is, and they agree that the person is famous and is possibly their idol or someone that they look up to in their respective industry.

\subsection{Leadership Styles and Attributes}

There are many styles of leadership that exists and among the prevalent ones are the autocratic (Vugt, Jepson, Hart, \& Cremer, 2004; Harms, Wood, Landay, Lester, \& Lester, 2018), the parental leadership (Bellon, Ngware, \& Admassu, 2017; Jang, 2015; Alstyne, 2010), the democratic (Al Khajeh, 2018; Allafchi, 2017), the laissez-faire (Al Malki \& Juan, 2018; Asrar-ul-Haq \& Kuchinke, 2016; Tarsik, Kassim, \& Nasharudin, 2014), the transactional, and transformational (Ozkan \& Ozturk, 2020; Toh, Liew, Rahim, \& Stephen, 2019) leadership styles.

\subsubsection{Autocratic Leadership}

Autocratic leaders are characterised by making decisions on his/her own without considering the views or inputs from his/her subordinates and/or followers. They are normally strict and keep a close monitoring of subordinates (De Cremer, 2006; Khan, Khan, Qureshi, Ismail, Rauf, Latif, \& Tahir, 2015). Among the attributes of autocratic leadership are: leaders would rely on threats and punishment to influence employees, they do not trust employees, they do not allow for employee input, and they have limited time in which to make a decision (Khan et al., 2015). This is a common sight for leaders in enforcement authorities like the army, police, customs, and immigration.

\subsubsection{Parental Leadership}

Meanwhile, parental leaders are leaders with dominant authority (Bellon et al., 2017; Bolivar \& Chrispeels, 2011), who treat their subordinates as though they are a part of a large, extended family (Douglass, Maroney, Coonan, Frieman, \& Carter, 2019). They are believed to be someone who always has their subordinate's best interests at heart (Oner, 2012). In return, the parental leaders expect to receive trust, loyalty, and obedience from his/her subordinates (Cheng, Chou, \& Wu, 2004).

\subsubsection{Democratic Leadership}

Democratic leadership, also known as participative or shared leadership, is a type of leadership style in which members of the group take a more participative role in 
the decision-making process (Sharma \& Singh, 2013). Subordinates are provided the chance to freely participate, generate ideas and exchanges, and discussions before decisions are finally made by the leader (Cherry, 2020). In the democratic process even though the process focuses on group equality and the free flow of ideas, an appointed leader is still needed to offer guidance and control (Amini, Mulavizada, \& Nikzad, 2019). The democratic manager keeps his or her employees informed about everything that affects their work and shares decision making and problem solving responsibilities (Khan et al., 2015).

This style of leadership requires the leader to have attributes, such as: a leader who has the final say but gathers information from subordinates before making a decision, produces high quality and high quantity work for long periods of time, develops plans to help employees evaluate their own performance, allows employees to establish goals, encourages employees to grow on the job and be promoted, and recognises and encourages achievement (Khan et al., 2015).

\subsubsection{Laissez-Faire Leadership}

Laissez-faire leadership style is also known as delegative leadership because the leaders delegate the tasks to their subordinates with little guidance (Al Malki \& Juan, 2018; Basit, Sebastian, \& Hassan, 2017). The leader provides little or no direction and gives employees as much freedom as possible. All authority or power is given to the employees and they must determine goals, make decisions, and resolve problems on their own (Khan et al., 2015). Among the attributes of a laissez-faire leaders are they do not provide regular feedback to let subordinates know how well they are doing, they are unable to thank their subordinates for their good work, and they do not understand their own responsibilities and hope the subordinates would cover for them (Khan et al., 2015).

\subsubsection{Transactional and Transformational Leadership}

The transactional leadership style suggests the use of reward and punishment system as a motivating factor to the employees, while the transformational leadership style focuses on moral exemplary approach of the leaders toward achieving benefits for the organisations (Baskarada, Watson, \& Cromarty, 2017).

Notwithstanding the number of leadership styles, for the purpose of this study, however, the researchers focused on both the transactional and transformational leadership styles, which are deemed appropriate in the Malaysian business environment. Jogulu and Ferkins (2012) argued that Malaysian cultural foundations contributed significantly to such leaderships in order to facilitate the creation of a harmonious leader-subordinate relationship. Also, it was found that transformational leadership has been identified 
as having a great impact on employee empowerment, as opposed to the transactional leadership style (Islam, Jantan, Rahman, Hamid, Mahmud, \& Hoque, 2018). Burns (1978) was the first to introduce the concepts of transforming and transactional leadership. Applying these leadership concepts by Burns (1978), Bass (1985) put the concepts into practice on a study of formal organisations and started delving into the psychological mechanisms lying beneath both "transformational" (renamed from "transforming") and transactional leaderships. The conceptualisation by Bass of these two leadership styles was validated and further refined by a number of scholars (Sashkin, 2004) such as Alimo-Metcalfe and Alban-Metcalfe (2001) and Avolio et al. (1999).

Leaders who exercise bureaucratic authority and legitimate power within the organisation are regarded as transactional leaders, and they accentuate on assigning tasks, standards of work, and employee compliance. Bass (1985) and Sashkin (2004) argued that transactional leaders rely on reward and punishment to influence employee behaviour whilst transformational leaders inspire followers by appealing to higher ideals and moral values (House \& Shamir, 1993). Studies have shown that transformational leadership represents four primary dimensions: idealised influence, inspirational motivation, intellectual stimulation, and individualised consideration (Avolio et al., 1999; Sashkin, 2004; Mittal, 2014). These leader characteristics are important because they invoke (1) strong responses from followers, such as performance beyond expectations (Judge \& Piccolo, 2004; Rowold \& Heinitz, 2007), (2) changes in the fundamental values held by followers and devotion to the leader (House \& Shamir, 1993; Kark \& Shamir, 2002; Sashkin, 2004), and (3) a willingness on the part of subordinates to sacrifice their personal interests for the collective good (Howell \& Shamir, 2005; Kark \& Shamir, 2002).

Both transactional and transformational leadership styles may be associated with a leader's moral and ethical orientation. Transformational leaders tend to be fundamentally concerned with doing what is "morally right" and protecting the rights and dignity of individuals; transactional leaders also share an interest in protecting the rights of others but tend to be more concerned with utility maximisation (Kanungo, 2001). Consistent with this perspective, transformational leaders have been shown to demonstrate higher perceived integrity (Aronson, 2004; Parry \& Proctor-Thomson, 2002), greater moral development (Turner et al., 2002), and more ethical behaviour (Aronson, 2004; Brown \& Trevino, 2006; Kanungo, 2001). Given the link between moral development and diversity (Demuijnck, 2009), it is anticipated that transformational leaders will take action more consistent with the spirit of inclusivity and social responsibility (Nishii \& Mayer, 2009). Transformational leaders may also be better able to convince followers that managing diversity is an important moral obligation and not simply an issue of legal compliance with government mandate (Gilbert et al., 1999; Leonard \& Grebler, 2006). 
Meanwhile, Eberlin and Tatum (2008), and Tatum, Eberlin, Kottraba, and Bradberry (2003) asserted that leadership styles may be linked to patterns of strategic decisionmaking and a leader's emphasis on differenttypes of justice. Specifically, transformational leaders tend to be more concerned with social justice, while transactional leaders tend to be more concerned with structural or procedural justice. Transformational leaders are inclined to place a strong emphasis on protecting the welfare of individuals in society and ensuring the fair treatment of all people in their actions (Hood, 2003; Tatum et al., 2003). In this regard, transformational leaders may be drawn to managing diversity because it will enhance the well-being of the organisation and its members (Kearney \& Gebert, 2009). Transactional leaders, on the other hand, tend to place a strong emphasis on following the rules and therefore may be more inclined to manage diversity to avoid punishment for non-compliance with legal standards (Hood, 2003).

Given that workplace diversity (Shaban, 2016) encompassing both social justice and compliance issue, transformational and transactional leadership styles should be implementing a certain level of diversity management practice. Social justice is concerned about minimising the level of biasedness and discrimination, and the enrichment of inclusion in the workplace (Gonzalez \& Zamanian, 2015). According to Gonzalez and Zamanian, "the social justice perspective includes the study of workplace discrimination and the implementation of diversity management programmes. Such programmes may be designed to meet legal compliance goals, such as following affirmative action and equal opportunity legislation" (p. 595, 2015). Transformational leaders will be motivated to manage diversity (De Vries \& Homan, 2008) because it is morally the right thing to do, while transactional leaders may be more motivated to comply with existing environmental pressures because it is good for business (Hussain, Abbas, Lei, Haider, \& Akram (2017). In the absence of these external pressures, however, the motivation for transactional leaders to implement diversity practices will likely diminish.

Having reviewed the various leadership styles and knowing that women play a vital role in enhancing the economic performance in Malaysia, it is vital for this study to explore and understand the attributes of prominent Malaysian women business leaders and their respective leadership styles.

\subsection{Research Method}

This study was conducted using the qualitative case study approach since there is a need to understand the reality of the case participants within their own respective settings and contexts. Qualitative case study methodology provides tools for researchers to study complex phenomenon within their contexts (Baxter \& Jack, 2008). Data for this study were gathered through semi-structured interviews because it provides a clear set 
of instructions for interviewers and can provide reliable, comparable qualitative data (Cohen \& Crabtree, 2006). The semi-structured interviews were conducted with three (3) prominent women business leaders who have agreed to participate in this study when we contacted them, and their employees (where possible), between the period of August 2014 to March 2015. Interviewees were asked questions related to their own or their superior's leadership style and leader attributes. Data were than triangulated from the interview data gathered from these case participants and personal observations made by the researchers during the interview visits (Flick, 2004).

All the interviews were transcribed and the transcription was constantly referred to in analysing the data. Data were analysed using thematic analysis (Braun \& Clarke, 2006). It involves the researchers to be familiarised with the data, identifying important features of the data that might be relevant to answer the research questions (for example by searching for the attributes conveyed about the prominent women business leaders) and coding them, searching for themes, reviewing themes, defining and naming themes, and finally, writing up which involves weaving together the analytic narrative and data extracts, and contextualising the analysis in relation to existing literature.

\subsection{Findings}

This paper presents a case study research conducted to understand and reveal the attributes and leadership styles of prominent women business leaders in Malaysia. The attributes and leadership styles of three (3) prominent women business leaders are being portrayed in this paper. Hence, the findings of this paper are structured according to the prominent women business leaders interviewed in this study.

For each of the prominent women business leader, it begins with the profile of the prominent women business leader and the organisation or business she represents, followed by her respective leading attributes and leadership styles.

\subsection{Datin Sharifah Anisah Tan Sri Dato’ Profesor Syed Agil Barakbah}

NR is a brand name under the MISB Resources Sdn. Bhd., which was established in December 2004. Ever since its establishment, MISB Resources Sdn. Bhd. is known as the pioneer in Malay herbal preparation products in Malaysia. Its factory has been awarded the Good Manufacturing Practice (GMP) status and since then, it has been under close scrutiny of the National Pharmaceutical Bureau. The factory is also supported by the QC/QA laboratories that will routinely conduct inspections of the raw materials, the packaging materials, and the end products to ensure guaranteed product quality and safety. All of the health products produced by MISB Resources Sdn. Bhd. under the brand name of NR are manufactured at 277, Lorong Perak 14, Mergong 
Industrial Estate II, 05150 Alor Setar, Kedah. The factory occupies an area of 10,000 square feet and has recruited more than 100 skilled employees from various areas and expertise.

Datin Sharifah Anisah Tan Sri Dato' Profesor Syed Agil Barakbah is the Chairman of the NR Group and founder of NR Mustajab. Born and raised in Alor Setar, Kedah, she received her early education in Kedah, Perak, and Johor. Datin Sharifah Anisah was the first Malay lady to be offered a scholarship in fine arts from the Royal Academy of Fine Arts, Munich, Germany, from which she graduated with flying colours. As an impressionist artist, she has won several art competitions at the national level.

Persistent requests from relatives and friends to assist in herbal medication and Malay traditional treatment in and around 1965 made Datin Sharifah Anisah reconsider her career path. Her success in treating the needy made her realise that she has knowledge and skills in herbal medication and traditional treatment. She learned to mix herbs in her kitchen, and became involved in pre-wedding treatment and treatment of mothers during their post-natal confinement. She also treated patients with gynaecological problems, such as fibroid tumour, infertility, hormone instability, and sexual dysfunction.

In 1991, her spa was identified as a model spa for Malay spa operators during the International Herbs Seminar held in Kuala Lumpur by the Institute of Medical Research and the World Health Organisation (WHO). She then established Nona Roguy Group of Companies in 1993 and marketed her products under the brand of Nona Roguy, which in Sanskrit means "free from diseases".

Datin Sharifah Anisah is a serious researcher and conducts investigations into the similarities and differences between traditional and modern medication. Active in associations related to the traditional medication industry and SMEs, Datin Sharifah Anisah has been appointed as the Vice President (Practice) of the Malaysian Association of Malay Traditional Medication (PUTRAMAS) and the Deputy President of the Small-Scale Industries Association of Malaysia.

\subsubsection{Leading Attributes and Influence}

Being concerned about their health and their family is the approach of Datin Sharifah Anisah in getting close to her staff members. This has resulted in the staff members becoming more open, and free to share their difficulties or problems. As mentioned by Tuan Syed, Finance and Strategic Planning Manager of MISB Resources Sdn. Bhd.: "When she visited the factory, Datin likes to listen to problems raised by the factory management down to the factory workers. Thus she is easy to mix around, and people are comfortable to convey their work problems to her. She makes herself approachable". 
According to Datin Sharifah Anisah, the staff members perceive her more as a mother than as a boss. She is comfortable with such perception because she enjoys being their confidante, someone who would listen to their problems and counsel them. That is how close she is to her staff. They would confide in her on all kinds of issues, including women's health and hygiene as well as marriage problems.

Datin Sharifah Anisah is also meticulous about staff appearance and grooming, specifically, the way they present themselves. As she enters the office, she would stop and say hello to all her staff, and even greet them at the washroom or during a meeting. Should she find or see anything not to her liking, she would immediately ask about it. She would not wait to call them into her room unless the issue is personal or would be offensive if she confronts the concerned staff openly. However, Datin Sharifah Anisah does not admonish the staff in front of other people as she very much believes that she should not reprimand, shout, or embarrass them in front of their colleagues.

Datin Sharifah Anisah is meticulous, carefully checking all reports submitted to her within 10 minutes of submission and handing them back for correction, even if it was just for language related mistakes. She would stay back after office hours to complete any outstanding tasks and does not procrastinate. Before calling it a day and the office lights are turned off, she would place the working papers on the desk of each staff concerned for their immediate action first thing the next morning. This practice has been acculturated in the staff and they do not delay their work as well. Tuan Syed further added:

"Datin is the type of person who would pursue a good idea till complete or successful. That showed how she appreciated a job. Be it 3am, she will work until the task is completed. It's very rare to see the tasks that she handled went incomplete. She would finish and complete most of the tasks. Out of 10, she would complete 8....unless there are hurdles that needed to be overcome. She's meticulous and whenever we want to hold a function, she'll check everything from A to $Z$, in terms of text of speeches, menu, programme itinerary. I can say that she's a perfectionist”.

Datin Sharifah Anisah is also a considerate boss who would not put unnecessary pressure on her staff. She would also allow her staff to complete the assigned tasks within the timeframe as agreed by both. She will take note of the deadline promised by her staff to ensure tasks are completed in a timely fashion. If a task is not completed on time, the staff must bring it to her attention a day before the deadline and hand-over the incomplete tasks to her and she can tolerate this, but not when deadlines are over and she is not informed. Staff members need to have good reasons for the failure to complete the assigned tasks. She would then stay up to complete the tasks herself. 
She does not hold grudges against anyone. If she dislikes someone, Datin Sharifah Anisah would just keep quiet, would not go near, or even look at that person and would remain silent. On the other hand, if it is someone she likes and has respect for, Datin Sharifah Anisah would approach that person to get to know him or her better. As highlighted by Tuan Syed again:

"Datin is not the type that would yell or scold people upfront when she's angry. She would call the person in, asked for explanation, and advised him or her. But of course from the advice we, as staff, would know if Datin is angry or upset. However, I would say, everybody [the staff] is close to her".

Appearance and dressing to suit the occasion are very important for Datin Sharifah Anisah. For example, if a person is a cook, then he or she should dress like a cook. Her philosophy is that staff must be healthy and eye-pleasing since NR is a business dealing with health and beauty products. She believes that her staff members are the ambassadors of NR products; hence, they have to be concerned with their health and pleasing in appearance so as to convince the existing and potential customers to buy NR products. As mentioned by Diana, a Senior Executive and Consultant, who has worked for her for more than 16 years now:

"Datin is very concerned about her staff's appearance. She likes it that they appear neat and tidy all the time”.

\subsubsection{Leadership Styles}

Datin Sharifah Anisah portrays a paternalistic style of leadership. She treats staff as family members inside and outside the organisation. She would always break the ice with her new staff by asking how they and their family members are doing. She is very concerned and encourages her staff to open up to her and share any difficulties and problems that they may be facing. She wants to be a mother figure and a counsellor, rather than a boss, to her staff. In her communication and interaction with her employees, her paternalistic attribute is very evident.

As Diana shared,

"Datin is a strict person. However, even though she is strict, she is full of love. She likes to share her knowledge and experience, she will explain. She likes things to be perfect the way she wants it to be. In addition, Datin can be our friend, our guidance. She is very energetic and of course she is my idol. She is my idol from the beginning until now. I will always 
follow her way of doing things. She might lead a modern lifestyle, but yet she maintains the traditional values and qualities. And I can see all the staffs are at ease with Datin. I have never seen Datin holding any grudges against the staff"'.

Datin Sharifah Anisah is also a leader who closely supervises her employees, giving her subordinates little discretion. She is meticulous about the way they look, their appearance, their hygiene, and grooming. Being in the business of health and cosmetics, Datin Sharifah Anisah believes that her employees are the ambassadors for their products, and hence, the need for them to portray a pleasing appearance and a healthy and glowing look.

Datin Sharifah Anisah is the type of leader who would retain all information and decision-making authority. She would provide her employees with a conducive working environment as well as fringe benefits. She believes that employees will work harder out of gratitude, trust, and loyalty. For instance, she would give warning to her staff to change or they would have to find a new place to work. This clearly indicates that Datin Sharifah Anisah is a stern leader; nonetheless, the employees realise that she means well and remain with her, working hard to achieve the goals of the company.

\subsection{Hajah Faiza Bawumi Sayed Ahmad}

Syarikat FAIZA was established in 1982, doing retail activities as its core business. In 1992, Syarikat FAIZA was officially incorporated under Syarikat FAIZA Sdn. Bhd. (SFSB), and went into venture capital with Padiberas Nasional (BERNAS) in 1997.

The vision held by SFSB is "to be the leader in the food industries in Malaysia which specialises in the production and distribution of specialty and high-end rice". SFSB has a solid infrastructure of rice production and distribution. The production plant is built on a total land area of 300,000 square feet, comprising high-tech equipment for rice processing and packaging, which can have a total production capacity of 12,000 metric tons per month, that is integrated with de-stoners, polishers, graders, and finally through colour-sorters and packaging. Overall the warehouse storage capacity is about 10,000 metric tons.

On the other hand, SFSB also has its own fleet of trucks and cars to handle distribution and sales service. With 40 units of lorries of multiple capacities and 20 units of sales cars, SFSB is ready to provide quality delivery and services to customers all over Malaysia. They have set a goal that any delivery must reach customers within three days from the order date for Johor perimeter and not exceeding five days for other territories. The maximum capacity of delivery is about 12,000 metric tons per month. 
Hajah Faiza Bawumi Sayed Ahmad is the Egyptian-born founder and owner of Syarikat Faiza Sdn. Bhd. She holds a Diploma in Sewing qualification. After a struggle of more than 47 years in the business world, how did she become a successful business woman? Hajah Faiza started her business by making and selling curry powders, under the brand name of Bunga Raya, and distributing them to stores. She then set up her own grocery shop. From there, she learned to recognise different types of rice. Hajah Faiza later applied for a wholesaler's license to sell various types of rice, including ponni rice, basmati rice, fragrant rice, and Siamese rice. Now, she has about 200 permanent employees and 300 contract workers involved in rice production. She also sells highquality products with halal status for the benefit of her Muslim customers.

\subsubsection{Leading Attributes and Influence}

Hajah Faiza is very passionate about doing business and is a hardworking woman. She does not waste her time unnecessarily. When she first started her business, she went from one house to another to sell her home-made curry powders. For her, learning and information search is important for her business to grow. That is the reason why when she wanted to sell rice under her own brand name, she conducted a market survey. She asked her existing customers whether they would buy her own brand name rice. After getting positive responses from her customers, she immediately applied for a wholesaler's license to enable her to sell various types of rice, as can be witnessed in the market today.

Hajah Faiza has an eye for detail. She records every single cent that is spent. If she happens to make mistakes when running the business, she would admit to it and learn from that mistake. Furthermore, she would share the lesson learnt with her employees for their own learning experience so that such mistakes are not repeated.

Hajah Faiza's intention to venture into business is very noble indeed. She wanted to become one of the biggest taxpayers and help the people in need. To achieve this laudable objective, she set up the Faiza Foundation to help the poor and single mothers. She is also a part of the "TV3 Bersamamu" programme and contributes part of her business profits to charity. Her other aim is to pay high zakat every year and contribute toward uplifting the Muslim community.

The researchers talked to the staff as well to try and identify Hajah Faiza's leadership style. According to Mr. Fikri who is the Control and Operations Manager with 13 years of experience in SFSB, Hajah Faiza is a charismatic lady. She is a warm person and easily gets along with people. He is full of admiration that she is a very determined person and will do her best to complete a task. She does not care how people label or look at her, and remains strong, while striving to handle any situation. This has sustained her in the rice business. Furthermore, she is inspiring and motivating, attributes which 
have resulted in her staff producing high quality work. She always stresses to the staff to be honest and trustworthy. Staff must come early to work as their job is an "amanah" from God, and they need to work to the best of their ability and beyond. Staff must respect and help each other as the occasion demands.

In addition, the business environment is like a 'home' where if the staff members have problems, they are free to consult Hajah Faiza. By doing so, it helps the company to progress and achieve its objectives as staff members are not troubled by personal problems and can concentrate on the task at hand. Even though Hajah Faiza's background is in tailoring, she has the knowledge on how to run a business. She likes to grab new opportunities and this is reflective of her intellectual stimulation attribute. She is a very hands-on person and wants to know what actually happens in the company. Whenever a new project is in the pipeline, before it can be executed, she will carefully consider the feasibility of the project and forecast its short and long-term implications. Sometimes, more time is needed to convince Hajah Faiza. Undeniably, Hajah Faiza's performance is beyond expectation. She shows high commitment and a passion to succeed. For her, if one truly endeavours, Allah will show the way for His servants. She believes that the rice production business of Syarikat Faiza is one of the "jihad" (the struggle or fight to enhance the wellbeing of oneself) in the Islamic economy.

Meanwhile, another staff member is Mr. Shamsudin, the Production and Logistics Manager, who has worked for 17 years with the company. He mentioned that Hajah Faiza defines and articulates the company's vision to the staff, and inspires them to carry it out. For management style, the company uses a bottom-up approach. The work culture is open and staff members (from lower level to management) are given the space to forward ideas to Hajah Faiza. Managers are empowered to conduct business operations. Furthermore, Hajah Faiza shows the spirit of inclusivity and social responsibility, whereby her motherly style has made the staff members feel happy working in the company. She treats the staff like her own children and always reminds them to pray.

Madam Hafezah, who is the Personal Assistant for Hajah Faiza, also revealed that her boss is an understanding person with a motherly heart. Hajah Faiza asks her staff to call her as "Ummi" so that less power distance exists between a boss and the staff. She is very open and, at any time, is willing to hear comments and advice from the staff. These characteristics have made Madam Hafezah loyal to Hajah Faiza and she has been serving SFSB for more than 13 years now.

\subsubsection{Leadership Styles}

Hajah Faiza Bawumi Sayed Ahmad displays transformational leadership attributes, including charisma, idealised influence, inspirational motivation, intellectual 
stimulation, and individual consideration. These attributes were confirmed by two of her staff members. From Mr. Fikri's perspective,

"Hajah Faiza is a charismatic lady. She is a warm person and easy to get along with”.

He admires her determination because she does not care how people would label or perceive her; she remains strong and determined in handling any situation. This quality has kept her going in the rice business.

She has the inspirational motivation attribute; she always stresses to the staff the importance of being honest and trustworthy. Staff members are required to come early to work and the job should be regarded as an "amanah" from the Almighty; hence, they need to work to the best of their ability, with a sense of respect and commitment to the company. She wants her employees to feel at home and if they have problems, they are free to consult her. Even though Hajah Faiza's background is tailoring, she knows how to run a business. She likes to grab new opportunities, and this is a reflection of the intellectual stimulation attribute. She is very detailed when it comes to work, and she wants to know what is actually happening in the company. For a new project to be carried out, she will always carefully consider the project and try to predict the shortterm and long-term implications of the project. Sometimes, more time is needed to convince Hajah Faiza.

Hajah Faiza is a person who displays performance beyond expectation. She shows high commitment and strives for success. She believes that if one makes the effort, the Almighty will show the way for His servants. She regards Syarikat Faiza as one of the "jihad" in developing the Islamic economy. Meanwhile Mr. Shamsudin mentioned that Hajah Faiza has defined and articulated the company's vision to the staff, and inspired the staff to carry it out. He finds that:

"Hajah Faiza practices a bottom-up management style, with an open work culture, where the staffs (from lower level to management) are given room to put forth their ideas and managers are empowered to conduct the business operations. In my opinion, Hajah Faiza shows the spirit of inclusivity and social responsibility, whereby her motherly style has made the staffs feel happy to work in her company. She treats the staff as though they are her own children and always reminds the staff to pray".

Based on the above confirmation, it can be said that Hajah Faiza holds a transformational leadership style. 


\subsection{Hajah Noor Hijerah Hanafiah}

Noor Arfa Holdings Sdn. Bhd. (also known as Noor Arfa Batik) is a pioneer of the much acclaimed batik industry in Malaysia. The Noor Arfa story had its humble beginnings in 1980 in a small atelier in Kuala Terengganu when the husband and wife team of Wan Mohd. Ariffin and Hajah Noor Hijerah started designing and hand-drawing their own batik cloth. The name "Noor Arfa" is an acronym, i.e., a combination of the names of this young and enterprising couple. It grew through leaps and bounds to become the multi-million dollar corporation it is today. The head office is situated at Lot 4153, Chendering Industrial Estate, 21080 Kuala Terengganu, Terengganu Darul Iman.

Always improvising and striving for the best in batik designs, Noor Arfa won the admiration and recognition from the local community for its meticulous designs and high quality fabrics. Noor Arfa enjoys the rare distinction of being the largest batik producer in the country, with distribution centres spread throughout the nation. With a strong force of more than 200 employees, Noor Arfa continues to strive for excellence in meeting the unique taste of every customer. This commitment right from the onset has been held steadfastly through almost two decades in the traditional batik industry. Noor Arfa is widely regarded as being ambitious, innovative, and entrepreneurial, both globally and locally.

\subsubsection{Leading Attributes and Influence}

Hajah Noor Hijerah Hanafiah is the owner Noor Arfa Holdings Sdn. Bhd. (or Noor Arfa, in short). She describes herself as a person who is receptive to change and challenges. When she first started the business, she was considered as a pioneer batik supplier in Terengganu with not much competition at that time. But now, the scenario has changed with many competitors in the market. Nonetheless, she did not panic; she viewed the competition positively and explored new markets and other products, such as women's accessories. She also ensures that her staff members are aware of the mission of the firm so that they can move ahead in tandem.

Hajah Noor Hijerah likes to acquire new knowledge and skills for her own betterment, and constantly explores new things. Such an enterprising spirit has made her what she is today. She said:

"I was merely a housewife before, but I didn't like to just sit at home waiting for my hubby to come back from work. I like traditional products but my passion in batik is the most. Thus, I had to do something about it".

Hajah Noor Hijerah perceives herself as a fast learner. While batik drawing is generally regarded as a difficult task and requires good skills, Hajah Noor Hijerah, 
being passionate, finds it easy to design. This is evidenced in her batik products. As a talented batik designer, she encourages and trains her staff to equip themselves with the required skills. She hopes that the acquired skills will enable her employees to perform well in the company.

The establishment of Noor Arfa Craft Complex (NACC) shows that Hajah Noor Hijerah is a visionary business woman. Even though she has to commit a huge investment in NACC, she believes that NACC will become a tourist destination. NACC offers a variety of high quality craft products manufactured in Terengganu and the east coast, generally. For her, NACC will act as an umbrella for all entrepreneurs and manufacturers of craft products (such as batik, "songket", "anyaman", glass craft, wood engraving, and copper-tooling). Thus, craft entrepreneurs would have the capability to supply high quality products that can compete in the market place.

Hajah Noor Hijerah cares very much about her staff's welfare. As described by Mrs. Nomi Ngah, the Accounts Manager who has worked for Noor Arfa for more than 24 years now:

"Puan Noor is really an amazing lady. Even though she's not much into management, since her husband, Encik Wan is the one overseeing the management of Noor Arfa Batik, she cares very much about her employees. She would always come down to the ground to observe how we work. She would also enquire into anything that she does not understand with regards to accounts. Also, the staffs feel at ease with Puan Noor that they regard her sometimes as an elder sister, or a mother. That's how Puan Noor approaches her staff".

She is a well-respected employer. She respects her staff and their family too. As added by Mrs. Nomi:

"Hajah Noor would normally provide us guidance, and show us how to do things correctly. So we feel as though we can confide almost anything to her. With the comfortable work surroundings and having a highly concerned boss, it suits me well and I don't think I would be looking for other jobs elsewhere".

As a show of respect, Hajah Noor Hijerah would reward her staff well for their good performance, such as in terms of providing them annual bonuses. Such recognition makes the staff feel valued. This is further emphasised by Mrs. Nomi:

"We have training for developing soft skills. Even Hajah Noor herself would conduct the training. These trainings are on a consistent basis". 
One of the staff said that Hajah Noor Hijerah never considers anything as hers. She is not bossy. She works as a team member. As a boss, Hajah Noor Hijerah ensures that certain positive values are integrated in her work and such values are also practised by her staff, such as integrity. She is modest, humble, polite and very well-behaved and does not like to show off. As Mrs. Nomi further described:

\begin{abstract}
"From a disciplinary perspective, what is practised in Noor Arfa Batik is similar to other organisations. The workers should know the discipline that they have to abide by. Making mistakes is regarded as normal but advice should be given accordingly, and staff should not be simply punished. Religious activities are also conducted here. Every month, the ustaz would come for solat and qiyamullail will be held once a year. We do not think we can get such knowledge elsewhere."
\end{abstract}

The staff members feel at ease working in Noor Arfa Batik because they feel that this is where they belong. As mentioned by Mrs. Nomi Ngah:

"Here, we have between 10 to 15 married couples. Puan Noor encourages marriage between the members of the staff".

\title{
4.3.2 Leadership Styles
}

Hajah Noor Hijerah Hanafiah has a transformational leadership style. One of her staff members, Mrs. Muni, an Accounts Executive, is inspired by her. She said that Hajah Noor Hijerah has clearly articulated the vision and mission of the company, rebranded the company from the previously known Noor Arfa Batik Sdn. Bhd., to the currently known Noor Arfa Holdings Sdn Bhd., aiming to expand its business scope. She ensures her ideas and suggestions are shared with the employees so that everyone in the company is aligned and thus move along the right direction of achieving the vision and mission. Her staff members have only admiration for her strength of character. Hajah Noor Hijerah believes with the teamwork spirit among the employees, Noor Arfa Holdings Sdn. Bhd. can perform beyond expectation and they can succeed farther together.

Hajah Noor Hijerah is a fast learner and generous in sharing her values and skills with staff and even tourists and visitors. It is fortunate that she likes to share her ideas with anyone who wishes to venture into the batik business. Her ultimate aim is to develop NACC as a business centre and a tourist attraction in Malaysia. Hajah Noor Hijerah wants her staff to succeed with her in Noor Arfa Holdings Sdn. Bhd., and she ensures all staff members are working in tandem. Her talent as a leader as well as a batik businesswoman is admired by not only her staff and their family members but also by the royal families of Terengganu and Kelantan, and this is indeed an honour. Indeed, over the years, the company has built an enviable reputation for itself and now stands squarely as one of the premier batik suppliers in the country. 
All the above demonstrate the transformational leadership of Hajah Noor Hijerah, which would not have been possible if not for Hajah Noor Hijerah articulating clearly the vision of the company, and inspiring her staff through her intellectual knowledge on batik, which has made Noor Arfa an immediately recognisable name in this country and beyond.

\subsection{Discussion}

The thematic analysis conducted on the attributes of three prominent women business leaders in their respective industries revealed that there are some common attributes.

The most prevailing attribute among these women business leaders is being visionaries. They have a clear vision and mission of what they are going to achieve and how to align their employees along the same path toward the achievement of the set goals. This is important for the success of the company, consistent with Taylor, Cornelius, and Colvin (2014), and Tracy (2016) who opined the same.

Another attribute is being meticulous. These leaders believe that focusing on details and being organised would help them to think systematically and to make the right decisions. This is crucial especially for fast-paced businesses. This seems to support the findings of De Cremer (2006) and Khan et al. (2015).

Providing support to Tracy (2016) and Bernasconi (2019), the participants suggested that a good leader must be full of determination, and be brave enough to venture into unchartered territory. They must be trend-setters, not mere followers. Based on their experience, the leaders interviewed suggested that being receptive to change and having the courage to face challenges are good qualities a leader should possess.

In addition, the participants highlighted that integrity is very crucial in doing business. It will ensure the sustainability of one's company. This was also highlighted by Edgeman et al. (1999) and Tracy (2016) in their articles on top qualities of great leaders. Being passionate about their work is another attribute of prominent women business leaders. This quality will motivate them to work hard and spend endless amount of time on their business, which eventually would contribute to its sustainability and competitive edge. Leaders with passion will inspire employees to be passionate in their work also, by expressing genuine enthusiasm and articulating why the organisation does what it does (Davies \& Brighouse, 2010).

The participants of this study also agreed that eloquence is very important to be a prominent leader. With the ability to speak flawlessly, leaders can sell their ideas confidently to both their employees and their clients. Their confidence will also be an inspiration to their employees. This supported the findings of Kim (2017). 
Apart from the above attributes, other criteria highlighted by the participants included: (i) being knowledgeable, (ii) being exemplary, (iii) being easy-going, (iv) having good communication skills, (v) being objective, and (vi) being engaged in continuous learning. These findings indicated that the Malaysian women business leaders have portrayed similar attributes as documented in overseas with other additional qualities (Karia \& Asaari, 2019; Yang \& Wei, 2017).

While the above attributes may be common for both prominent men and women leaders, one unique attribute highlighted in this study would be the motherly/sisterly approach portrayed by most participants (Amran et al., 2017). Such an approach has made employees feel comfortable with their respective leaders and has encouraged them to be willing to open up when facing problems at work.

\subsection{Conclusion}

In summary, the results revealed that there are a number of attributes of prominent women business leaders that are worth sharing. The main attributes which are consistent with the previous literature on top qualities of great leaders include, (i) being visionary, (ii) being meticulous, (iii) being determined, (iv) having integrity, (v) being passionate, and (vi) being an eloquent speaker. These same criteria drive businessmen as well.

In addition, the findings revealed that there are two types of leadership styles demonstrated by the prominent women business leaders in this case study, namely the paternalistic and the transformational leadership styles. Irrespective of their styles, the participants had proven that their approach has been successful in sustaining their business.

It is hoped that these findings would add to the existing literature on leadership attributes and styles of women business leaders, particularly in the ASEAN region. Practically, the findings would be of importance to young entrepreneurs who aspire to be industry leaders. This information can be shared during training sessions or seminars with women entrepreneurs in order to boost their confidence level and commitment to succeed. Similarly, these attributes may be shared among graduates who are interested to venture into business in the future.

This study is not without its limitations. As generally known, this study is a qualitative case study on three (3) prominent women business leaders in Malaysia. Hence, the results cannot be generalised to the general population. Hence, more future studies may need to be conducted to understand the leadership attributes and leadership styles of women in Malaysia. Their leadership style may be attributable to the nature of the industry that 
they are engaged in. However, no further tests were done on such a possibility, which provides another avenue for future research. Furthermore, the participants originated from one ethnic group only, i.e., the Malays. It would be interesting for future studies to include Chinese and Indian women business leaders.

\section{Acknowledgements}

The authors would like to note their highest appreciation to the Universiti Utara Malaysia for granting the researchers the funding to enable them to conduct and complete this study.

\section{References}

Abdullah, S. N., Ku Ismail, K. N. I., \& Nachum, L. (2016). Does having women on boards create value? The impact of societal perceptions and corporate governance in emerging markets. Strategic Management Journal, 37(3), 466-476.

Alam, S. S., Jani, M. F. M., \& Omar, N. A. (2011). An empirical study of success factors of women entrepreneurs in Southern Region in Malaysia. International Journal of Economics and Finance, 3(2), 166-175.

Alimo-Metcalfe, B., \& Alban-Metcalfe, R. J. (2001). The development of a new transformational leadership questionnaire. Journal of Occupational and Organisational Psychology, 74(1), 1-27.

Al Khajeh, E. H. (2018). Impact of leadership styles on organisational performance. Journal of Human Resources Management Research, 2018, 1-10.

Allafchi, N. (2017). Effect of democratic leadership style on management of communication with customers in Melli Banks of Hamedan. International Journal of Cultural and Social Studies, 3(2), 168-179.

Al Malki, M., \& Juan, W. (2018). Impact of laissez-faire leadership on role ambiguity and role conflict: Implications for job performance. International Journal of Innovation and Economic Development, 4(1), 29-43.

Alstyne, B. V. (2010). Parental leadership: The Mary Poppins metaphor. Journal of Conscious Evolution, 5, 1-6.

Amini, M. Y., Mulavizada, S., \& Nikzad, H. (2019). The impact of autocratic, democratic and laissez-faire leadership style on employee motivation and commitment: A case study of Afghan wireless communication company (AWCC). IOSR Journal of Business and Management, 21(6), 45-50.

Amran, N. A., Saad, N., Abdullah, Z., \& Ibrahim, M. (2017). Leadership style in transforming the business landscape. Journal of Business Management and Economic Studies, 2(2), 52-62.

Aronson, J. (2004). The threat of stereotype. Educational Leadership, 62, 14-20. 
Asrar-ul-Haq, M., \& Kuchinke, K. P. (2016). Impact of leadership styles on employees' attitude towards their leader and performance: Empirical evidence from Pakistani banks. Future Business Journal 2, 2016, 54-64.

Avolio, B. J., Bass, B. M., \& Jung, D. I. (1999). Re-examining the components of transformational and transactional leadership using the multifactor leadership. Journal of Occupational and Organisational Psychology, 72(4), 441-462.

Aziz, H. (2016). Merdeka set education for women right. New Straits Times, 31 August 2016. Retrieved April 2, 2020, from https://www.google.com/amp/s/www.nst. com.my/node/169 537/amp.

Basit, A., Sebastian, V., \& Hassan, Z. (2017). Impact of leadership style on employee performance (A case study on a private organisation in Malaysia). International Journal of Accounting and Business Management, 5(2), 112-130.

Baskarada, S., Watson, J., \& Cromarty, J. (2017). Balancing transactional and transformational leadership. International Journal of Organisational Analysis, 25(3), 506-515.

Bass, B. M. (1985). Leadership and performance beyond expectation. New York, NY: Free Press.

Bass, B. M., Avolio, B. J., Jung, D. I., \& Berson, Y. (2003). Predicting unit performance by assessing transformational and transactional leadership. Journal of Applied Psychology, 88, 207-218.

Baxter, P. E., \& Jack, S. M. (2008). Qualitative case study methodology: Study design and implementation for novice researchers. Qualitative Report, 13(4), 544-559.

Bellon, E. O., Ngware, M. W., \& Admassu, K. (2017). The role of parental leadership in academic performance: A case of pupils in the free primary education program in Kenya. Education and Urban Society, 49(1), 110-130.

Bernasconi, F. Y. (2019). Determination is key to successful leaders. Retrieved April 14, 2020, from https://sites.psu.edu/leadership/2019/09/12/determination-iskey-to-successful -leaders/.

Bolivar, J. M., \& Chrispeels, J. H. (2011). Enhancing parent leadership through building social and intellectual capital. American Educational Research Journal, 48(1), 4-38.

Braun, V., \& Clarke, V. (2006). Using thematic analysis in psychology. Journal of Qualitative Research in Psychology, 3(2), 77-101.

Brown, M. E., \& Trevino, L. K. (2006). Ethical leadership: A review and future directions. The Leadership Quarterly, 17(6), 595-616.

Burns, J. M. (1978). Leadership. New York, NY: Harper and Row.

Cheng, B. S., Chou, L. F., \& Wu, T. Y. (2004). Paternalistic leadership and subordinate responses: Establishing a leadership model in Chinese organisations. Asian Journal of Social Psychology, 7, 89-117.

Cherry, K. (2020). The democratic style of leadership. Retrieved April 8, 2020, from https://www.verywellmind.com/what-is-democratic-leadership-2795315. 
Cohen, D., \& Crabtree, B. (July, 2006). Qualitative research guidelines project. Retrieved April 8, 2020, from http://www.qualres.org/HomeSemi-3629.htm.

Davies, B., \& Brighouse, T. (2019). Passionate leadership. British Educational Leadership, Management, and Administration Society, 24(1), 1-3.

De Cremer, D. (2006). Affective and motivational consequences of leader self-sacrifice: The moderating effect of autocratic leadership. The Leadership Quarterly, 17, 79-93.

Demuijnck, G. (2009). Non-discrimination in human resources management as a moral obligation. Journal of Business Ethics, 88, 83-101.

Department of Statistics Malaysia (2019). Retrieved April 4, 2020, from https://www. dosm. gov.my/.

Densten, I. L. (1999). Senior Australian law enforcement leadership under examination. Policing and International Journal of Police Strategies and Management, 22(1), 45-57.

De Vries, G., \& Homan, A. C. (2008). Diversity and leadership: Transformational leadership and its role in managing diversity. Gedrag en Organisatie, 21(3), 295309.

Douglass, A. L., Maroney, M. R., Coonan, M., Friedman, D. H., \& Carter, A. (2019). You have a status: A case study of parent leadership in a U.S. school readiness initiative. International Journal of Child Care and Education Policy, 13(2), 1-21.

Eberlin, R. J., \& Tatum, B. C. (2008). Making just decisions: Organisational justice, decision making, and leadership. Management Decision, 46(2), 310-329.

Edgeman, R. L., Dahlgaard, S. M. P., Dahlgaard, J. J., \& Franz, S. (1999). On leaders and leadership. Quality Progress, 32(10), 49-54.

Farh, J. L., \& Cheng, B. S. (2000). A cultural analysis of paternalistic leadership in Chinese organisations. In J. T. Li., A. S. Tsui, \& E. Weldon (Eds.), Management and organisations in the Chinese context (84-127). London: Macmillan.

Farh, J. L., Cheng, B. S., Chou, L. F., \& Chu, X. P. (2006). Authority and benevolence: Employees' responses to paternalistic leadership in China. In A. S. Tsui, Y. Bian, \& L. Cheng (Eds.), China's domestic private firms: Multidisciplinary perspectives on management and performance (230-260). New York: Sharpe.

Flick, U. (2004). Triangulation in qualitative research. In a companion to qualitative research. 3, 178-183. Accessed from https://books.google.com.my/books? hl=en \&lr $=\& \mathrm{id}=61 \mathrm{wPkSo} 2 \mathrm{XW} 8 \mathrm{C} \& \mathrm{oi}=\mathrm{fnd} \& \mathrm{pg}=\mathrm{PP} 194 \& \mathrm{dq}=$ Flick $+2004+\mathrm{t}$ riangulation+in+qualitative+research $\&$ ots $=\mathrm{Zq}--5 \mathrm{oWs} I \mathrm{k} \& \mathrm{sig}=-\mathrm{ncC} 5 \mathrm{fWe}-$ VLTvi8abm1M8dcpCBc\#v=onepage \&q=Flick\%202004\%20triangulation \%20 in\%20qualitative\%20research\&f=false $<<$ Artikel dalam e-buku $>>$ on May $19^{\text {th }}$, 2020 at $12 \mathrm{pm}$.

Gelfand, M. J., Erez, M., \& Aycan, Z. (2007). Cross-cultural organisational behaviour. Annual Review of Psychology, 58, 479-514.

Gilbert, J. A., Stead, B. A., \& Ivancevich, J. (1999). Diversity management: A new organisational paradigm. Journal of Business Ethics, 21(1), 61-76. 
Gonzalez, J. A., \& Zamanian, A. (2015). Diversity in organisations. Diversity in organisations. In J. D. Wright (Ed.), International Encyclopaedia of the Social and Behavioural Sciences (2nd ed.), Volume 6 (595-600). Oxford: Elsevier

Harms, P. D., Wood, D., Landay, K., Lester, P. B., \& Lester, G. V. (2018). Autocratic leaders and authoritarian followers revisited: A review and agenda for the future. The Leadership Quarterly, 29(1), 105-122.

Hays (2018). Number of women in management rises in Malaysia. Retrieved April 5, 2020, from https://hrasiamedia.com/top-news/2018/number-of-women-inmanagement-rises-in-malaysia/.

Hirschmann, R. (2020). Students in public higher education institutions in Malaysia 2012-2018 by gender. Retrieved April 4, 2020, from https:/www.statista.com/ statistics/794845/students-in-public-higher-education-institutions-by-gendermalaysia/.

Hood, J. N. (2003). The relationship of leadership style and CEO values to ethical practices in organisations. Journal of Business Ethics, 43(4), 263-273.

Howell, J., \& Avolio, B. (1993). Transformational leadership, transactional leadership, locus of control and support for innovation: Key predictors of consolidatedbusiness-unit performance. Journal of Applied Psychology, 78, 891-902.

Howell, J. M., \& Shamir, B. (2005). The role of followers in the charismatic leadership process: Relationships and their consequences. Academy of Management Review, 30(1), 96-112.

House, R. J., \& Shamir, B. (1993). Toward the integration of transformational, charismatic and visionary theories. Academic Press.

Hussain, S. T., Abbas, J., Lei, S., Haider, M. J., \& Akram, T. (2017). Transactional leadership and organisational creativity: Examining the mediating role of knowledge sharing behaviour. Journal Cogent Business and Management, 4(1), 1-12.

Idris, F., \& Ali, M. K. A. (2008). The impacts of leadership style and best practices on company performances: Empirical evidence from business firms in Malaysia. Total Quality Management and Business Excellence, 19(1-2), 163-171.

Islam, M. A., Jantan, A. H., Rahman, M. A., Hamid, A. B. A., Mahmud, F., \& Hoque, A. (2018). Leadership styles for employee empowerment: Malaysian retail industry. Journal of Management Research, 10(4), 27-40.

Jang, Y. (2015). Effects of parental leadership and verbal control modes on preschool children's leadership. The Korean Journal of Community Living Science, 26(2), 249-259.

Jogulu, U., \& Ferkins, L. (2012). Leadership and culture in Asia: The case of Malaysia. Asia Pacific Business Review, 18(4), 1-19.

Judge, T. A., \& Piccolo, R. F. (2004). Transformational and transactional leadership: A meta-analytic test of their relative validity. Journal of Applied Psychology, 89(5), 755. 
Kanungo, R. N. (2001). Ethical values of transactional and transformational leaders. Canadian Journal of Administrative Sciences, 18(4), 257-265.

Karia, N., \& Asaari, M. H. A. H. (2019). Leadership attributes and their impact on work-related attitudes. International Journal of Productivity and Performance Management, 68(5), 903-919.

Karim, S. A., \& Azmi, I. A. G. (2008). Muslim women entrepreneurs: A study on success factors. In the Proceeding of National Islamic Entrepreneur Seminar II, Islamic Studies Academy, Universiti Malaya, on 15 October 2008.

Kark, R., \& Shamir, B. (2002). The influence of transformational leadership on follower's relational versus collective self-concept. Academy of Management Proceedings, 2002(1), D1-D6.

Kearney, E., \& Gebert, D. (2009). Managing diversity and enhancing team outcomes: The promise of transformational leadership. Journal of Applied Psychology, 94(1), 77-89.

Khan, M. S., Khan. I., Qureshi, Q. A., Ismail, H. M., Rauf, H., Latif, A., \& Tahir, M. (2015). The styles of leadership: A critical review. Public Policy and Administration Research, 5(3), 87-92.

Kim, L. (2017). Do you have these 7 important leadership qualities. Retrieved April 15, 2020, from https://medium.com/marketing-and-entrepreneurship/do-youhave -these-7-important-leadership-qualities-c98a3a32a366.

Ku Ismail, K. N. I., Amran, N. A., Aripin, N., Abd. Manaf, K. B., \& Abdullah, S. N. (2017). Women representation on boards of Malaysian companies and firm characteristics. JGD, 13(1), 13-32.

Lewin, K., Llippit, R., \& White, R. K. (1939). Patterns of aggressive behaviour in experimentally created social climates. Journal of Social Psychology, 10, 271301.

Leonard, A., \& Grebler, A. F. (2006). Exploring challenges to managing transformational leadership communication about employment equity: Managing organisational change in South Africa. Journal of Communication Management, 10(4), 390406.

Malaysia Demographics Profile (2019). Retrieved March 30, 2020, from https://www. index mundi.com/malaysia/demographics_profile.html.

Merican, J., \& Ghani, S. (2016). Advancing the women agenda: Where is Malaysia at now? Retrieved April 1, 2020, from http://www.leaderonomics.com.

Ministry of Women, Family and Community Development, Malaysia (2019). Malaysia ranks high in women's educational attainment, The Malay Mail, 7 November 2019.

Mittal, R. (2014). Charismatic and transformational leadership styles: A cross-cultural perspective. International Journal of Business and Management, 10(3), 26-33.

Nishii, L. H., \& Mayer, D. M. (2009). Do inclusive leaders help to reduce turnover in diverse groups? The moderating role of leader-member exchange in the diversity to turnover relationship. Journal of Applied Psychology, 94(6), 1412-1426. 
Oner, Z. H. (2012). Servant leadership and paternalistic leadership styles in the Turkish business context. Leadership and Organisational Development Journal. Vol. 33 No. 3, pp. 300-316. https://doi.org/10.1108/01437731211216489

Ozkan, O., \& Ozturk, I. (2020). Impact of organisational culture and leadership styles on employee performance: A research study on the banking industry. Research Journal of Business and Management, 7(1), 45-55.

Parry, K. W., \& and Proctor-Thomson, S. B. (2002). Perceived integrity of transformational leaders in organisational settings. Journal of Business Ethics, 35(2), 75-96.

Pellegrini, E. K., \& Scandura, T. A. (2006). Leader-member exchange (LMX), paternalism and delegation in the Turkish business culture: An empirical investigation. Journal of International Business Studies, 37(2), 264-279.

Perianes, M. B. (2018). Investing in women is smart economics. Retrieved April 1, 2020, from https://medium.com/datadriveninvestor/investing-in-women-is-smrteconomics-97f 3ee6446ef.

Revenga, A., \& Shetty, S. (2012). Empowering women is smart economics. Finance and Development, March, 40-43.

Rowold, J., \& Heinitz, K. (2007). Transformational and charismatic leadership: Assessing the convergent, divergent and criterion validity of the MLQ and the CKS. The Leadership Quarterly, 18(2), 121-133.

Sashkin, M. (2004). Transformational leadership approaches: A review and synthesis. In J. Antonakis, A. T. Cianciolo, \& R. J. Sternberg (Eds.). The Nature of Leadership (171-196). Sage Publications, Inc.

Schepers, J., Wetzel, M., \& Ruyter, K. D. (2005). Leadership styles in technology acceptance: Do followers practice what leaders preach? Managing Service Quality, 15(6), 496-508.

Shaban, A. (2016). Managing and leading a diverse workforce: One of the main challenges in management. Procedia - Social and Behavioural Sciences, 230, 76-84.

Sharma, L. J. K., \& Singh, S. K. (2013). A study on the democratic style of leadership. International Journal of Management and Information Technology, 3(2), 54-57.

Smith, A. (1998). International crises and domestic politics. The American Political Science Review, 92(3), 623-638.

Tarsik, N. F., Kassim, N. A., \& Nasharudin, N. (2014). Transformational, transactional or laissez-faire: What styles do university librarians practice? Journal of Organisational Management Studies, 2014, 1-10.

Tatum, B. C., Eberlin, R., Kottraba, C., \& Bradberry, T. (2003). Leadership, decision making and organisational justice. Management Decision, 41(10), 1006-1016.

Taylor, M. T., Cornelius, C. J., \& Colvin, K. (2014). Visionary leadership and its relationship to organisational effectiveness. Leadership and Organisation Development Journal, 35(6), 566-583. 
The New Straits Times (September 24, 2018). Government wants 30 percent women in decision making positions by 2030. Retrieved Aril 1, 2020, from https://www. ggogle.com /amp/s/www.nst.com.my/node/414388/amp.

The Star (March 9, 2011). Shahrizat: Appoint more women at decision-making level, 4.

The Star (October 17, 2019). Women representation on PLC boards is still low. Retrieved April 1, 2020, from https://www.thestar.com.my/business/businessnews/2019/10/17/wo men-representation-on-plc-boards-is-still-low.

Toh, P. S., Liew, W. J., Rahim, I. H. A., \& Stephen, S. (2019). Transformational and transactional leadership styles towards organisational commitment in the hotel industry. Journal of Tourism, Hospitality, and Environment Management, 4(17), 34-45.

Tracy, B. (2016). The seven leadership qualities of great leaders. Retrieved April 1, 2020, from http://www.briantracy.com/blog/leadership-success/the-sevenleadership-qualities-of-great-leaders.

Turner, N., Barling, J., Epitropaki, O., Butcher, V., \& Milner, C. (2002). Transformational leadership and moral reasoning. Journal of Applied Psychology, 87, 304-311

Turner, N., Barling, J., Epitropaki, O., Butcher, V., \& Milner, C. (2002). Transformational leadership and moral reasoning. Journal of Applied Psychology, 87, 304-311

Turner, N., Barling, J., Epitropaki, O., Butcher, V., \& Milner, C. (2002). Transformational leadership and moral reasoning. Journal of Applied Psychology, 87, 304-311

Turner, N., Barling, J., Epitropaki, O., Butcher, V., \& Milner, C. (2002). Transformational leadership and moral reasoning. Journal of Applied Psychology, 87, 304-311.

Vugt, M. V., Jepson, S. F., Hart, C. M., \& Cremer, D. D. (2004). Autocratic leadership in social dilemmas: A threat to group stability. Journal of Experimental Social Psychology, 40(1), 1-13.

Wartzman, R. (2013). Do women make better corporate leaders than men? Retrieved April 15, 2020, from https://www.forbes.com/sites/drucker/2013/04/02/womenbetter-corporate -leaders/.

Yammarino, F. J., Spangler, W. D., \& Bass, B. M. (1993). Transformational leadership and performance: A longitudinal investigation. The Leadership Quarterly, 4(1), 81-102.

Yang, Q., \& Wei, H. (2017). Ethical leadership and employee task performance: Examining moderated mediation process. Management Decision, 55(7), 15061520. 